INTERNATIONAL JOURNAL OF RESEARCHES IN BIOSCIENCES, AGRICULTURE AND TECHNOLOGY (c) VISHWASHANTI MULTIPURPOSE SOCIETY (G lobal Peace Multipurpose Society) R. No. MH-659/13 (N) www.vmsindia.org

\title{
OCCURRENCE AND DISTRIBUTION OF ARBUSCULAR MYCORRHIZAL FUNGI FROM RHIZOSPHERE AND NON- RHIZOSPHERE SOIL OF SELECTED LOCALITIES OF PARNER TEHSIL
}

\section{K. Dhumal ${ }^{1}$ and R. K. Aher ${ }^{2}$}

\author{
${ }^{1} \mathrm{New}$ Arts Commerce And Science College Ahmednagar,414001,M.S.India \\ $2 \mathrm{New}$ Arts Commerce And Science CollegeParner,414302,M.S.India \\ lata_dhumal@rediffmail.com
}

\begin{abstract}
:
ArbuscularMychorrhizal (AM) species diversity and their root colonization patterns may vary in a plant species is influenced by environmental and biological factors. In the present study Rhizos phe ric and Non - Rhizos phe ric soils were collected from five localities of Parner Tehsil. Soli mycoflora was studied at vegetative stages of growth. Occurrence and distribution of Rhizosphere mycoflora was dominant over Non - Rhizosphere. The most Mycorrhizal fungi like Acaulosporaelegans, A.foveata, A. laevis, Glomus aibidium, G. fasciculatum, G. globiferum, G. mosseae, G. versiformae etc.
\end{abstract}

Keywords: ArbuscularMycorrhizal, Rhizos phe re and Non - Rhizosphere, Mycorrhizal root colonization, Parner.

\section{Introduction}

Frank (1885) first gave the name Mycorrhiza to describe the essential structure and functioning of the peculiar associations between the roots and ectomycorrhizal fungi.

ArbuscularMychorrhiza are considered as obligate biotrophic symbionts and are associated with the fine roots of over $80 \%$ te rrestrial plant species.(Smith \&Read 1997). In this plant fungus association, fungus depends upon host plant for nutrition and reproduction, and in return provides phosphates and essential mineral nutrients from soil to the host plant. Colonization by ArbuscularMycorrhizal fungi assures good survival and growth of plants. (Vijaykumar and Abraham, 2001; Lakshaman\&Patil, 2004)AM belongs to Zygomycete order Glomales.

The main function of AM fungi is of phosphorous transportation. Extra radical mycelium of AM fungi easily access $\mathrm{P}$ from soil and deliver to root cortical cells as polyphosphate which finally translocate to host plant after solubilization and it is estimated that external hyphae deliver up to $80 \%$ of $\mathrm{P}$ require ment of the plant( Matamoros et.al 1999) .Other than $\mathrm{P}$ translocation ,AM fungi provides protection to the host plant roots from soil borne pathogenic attack they improve tole rance of plants to several abiotic stresses including drought, and saline stress condition by producing plant growth hormones (Evelin et.al,2009). In addition Mychorrhizal association also enhances nitrogen uptake as well as utilization of several micro nutrients AM successfully colonize with a wide range of plant species and are considered as non-host specific (Evelin et.al 2009). Additionally diffe rent species of AM fungi differ in their tolerance to adverse physical and chemical condition in soil (Kumar and Ghose, 2008).

In present study the mycoflora of Rhizospheric and Non - Rhizospheric soil of some selected localities of Parner Tehsil was studied.

\section{Materials and Methods:}

The Rhizospheric and non-Rhizosphe ric soil samples were collected from five selected areas of Parner Tehsil, areas like TakaliDhokeshwar, Wasunde, Khadakwadi, Padali Terfe Kanhur Pathar, and Hiware Korda. All the ten soil samples were brought to laboratory in sealed polythene bags. Then these samples were air dried in the shade at laboratory temperature .Then these samples were analyzed to its chemical parameters from the Agricultural Institute to examine its $\mathrm{pH}$, salinity, organic carbon, Phosphorous,Pottassium, Copper, Iron, Zink \&mangenese.

One third part of each collected soil sample was used for AM spore extraction using the method described by Gerdemann\& Nicolson (1963). In each case $50 \mathrm{gm}$ of sample was mixed with $500 \mathrm{ml}$ water followed by through stirring and then suspension was sieved through a series of sieves. Spores were collected on the filter paper and then counted using binocular compound microscope. 


\section{Results and Discussion:}

AM isolated from Rhizosphere and NonRhizosphere soil of five different localities of Parner Tehsil are presented in Table No-1

In the Rhizospheric soil of 5 different localitie s 11-14 AM were isolated from vegetative stage.Non -Rhizospheric soil was also studied 7 8 AM were isolated from vegetative stage.
Total 20 species of ArbuscularMycorrhizal fungi were isolated and identified from Rhizosphere and non Rhizosphere soil of five different localities from Parner Tehsil. It was clearly seen that species belonging to the three genera (Acaulospora, Glomus, Scutellispora) of AMF. Glomus species was most dominated than others two.

Table 1- Occurre nce and distribution of ArbuscularMycorrhizal fungi from Rhizosphere and non Rhizosphere soil of selected localities of Parner Te hsil

\begin{tabular}{|c|c|c|c|c|c|c|c|c|c|c|}
\hline \multirow{2}{*}{$\mathrm{AMF}$} & \multicolumn{2}{|c|}{ Wasunde } & \multicolumn{2}{|c|}{ TakaliDhokeshwar } & \multicolumn{2}{|c|}{ Khadakwadi } & \multicolumn{2}{|c|}{ Padalitarfe KanhurPathar } & \multicolumn{2}{|c|}{ HiwareKorada } \\
\hline & \begin{tabular}{|l|}
$\begin{array}{l}\text { Rhizo } \\
\text { soil }\end{array}$ \\
\end{tabular} & \begin{tabular}{|l|} 
Non \\
Rhizo
\end{tabular} & $\begin{array}{l}\text { Rhizo } \\
\text { s oil }\end{array}$ & $\begin{array}{l}\text { Non } \\
\text { Rhizo }\end{array}$ & \begin{tabular}{|l|} 
Rhizo \\
soil
\end{tabular} & $\begin{array}{l}\text { Non } \\
\text { Rhizo }\end{array}$ & Rhizo soil & $\begin{array}{l}\text { Non } \\
\text { Rhizo }\end{array}$ & \begin{tabular}{|l} 
Rhizo \\
s oil
\end{tabular} & $\begin{array}{l}\text { Non } \\
\text { Rhizo }\end{array}$ \\
\hline Acaulosporafoveata & + & $-{ }_{-1}$ & + & - & + & - & + & - & + & - \\
\hline Acaulosporalaevis & + & + & + & - & + & - & - & - & + & - \\
\hline Acaulosporaelegans & - & - & - & + & + & - & + & + & + & + \\
\hline Glomus aggregatum & + & + & + & + & + & + & + & - & + & - \\
\hline Glomus albidium & - & + & - & + & - & + & - & + & - & + \\
\hline Glomus constrictum & + & - & + & - & - & - & - & + & + & - \\
\hline Glomus dimorphicum & - & - & + & - & + & - & + & - & + & - \\
\hline Glomus etunicatum & + & - & - & + & + & - & - & - & + & + \\
\hline Glomus fasciculatum & + & + & + & + & + & + & + & + & + & + \\
\hline Glomus geosporum & + & + & + & - & + & + & + & - & + & + \\
\hline Glomus globiferum & + & - & - & - & + & - & + & - & + & - \\
\hline Glomus heterosporum & + & - & + & + & - & - & + & + & - & - \\
\hline Glomus macrocarpum & + & + & + & + & + & + & + & - & + & + \\
\hline Glomus monospermum & - & - & - & - & + & + & - & - & - & - \\
\hline Glomus trimurales & + & - & + & - & + & - & + & - & + & - \\
\hline Scutellisporadipurpurascens & - & - & + & - & - & + & - & - & + & - \\
\hline Scutellisporagregaria & + & + & + & + & + & - & + & + & + & + \\
\hline Scutellisporahe terogama & + & - & + & - & + & - & + & - & + & - \\
\hline Scutellisporanigra & + & + & + & + & + & + & + & + & + & + \\
\hline
\end{tabular}

\section{Conclusions:}

From the above observation table it was concluded that the species of Glomus were more diverse than the Acaulospora, Scutellispora. Glomus macrocarpum, G.fasciculatum, G.gigasporum was more dominated in both Rhizo as well as Non -Rhizospheric soil.

\section{Acknowledgements:}

The authors are thankful to Principle of New Arts Commerce and Science College, Ahmednagar, and Head of Department of Botany, New Arts Commerce and Science College Ahmednagar for providing necessary facilities for this work. The authors are also thankful to Principle of New Arts Commerce and Science College, Parner for encouragement and support.

\section{References:}

Abbott LK, Robson AD, 1984. The effect of VA mycorrhizae on plant growth. In: Powell CL,

Abbott LK, Robson AD, 1991. Factors influencing the occurrence of vesicular-Arbuscular mycorrhizae. Agr. Ecosys. Environ.35: 121-150.
Aliasgharzadeh N, Saleh Rastin N, Towfighi H, Alizadeh A, 2001. Occurrence of ArbuscularMycorrhizal fungi in saline soils of the Tabriz plain of Iran in relation to some physical andche mical properties of soil. Mycorrhiza 11: 119122.

Bagyaraj DJ. (ed.) Mycorrhizae. pp. 113-130.Boca Raton, Florida, USA: CRC Press.

Bagyaraj D.J., 1984. Biological interactions with VA Mycorrhizal fungi. In: VA Mycorrhiza (Ed. Powell, C.L. and Bagyaraj, D.J.) CRC Press, Florida. pp. 131-154

Brundrett M. (2004). Diversity and classification of Mycorrhizal associations. Biol Rev, 79: 473-495

David, M. Sylvia. And Jacob, N. Burks. (1988). selection of a vesicular-ArbuscularMycorrhizal fungus for practical inoculation of Uniolapaniculata. Mycologia , 80 (4): 565-568.

Gerdemann JW and Nicolson TH., 1963. Int.J.Curr.Microbiol.App.Sci(2014) 3(6): 527-539

538 Spores of MycorrhizalEndogone species extracted from soil by wet sieving and decanting. Trans Br Mycol Soc. 46(2):235-244.

Gianinazzi-Person, M. and Gianinazzi, V. (1994). Biodiversity in Arbuscular fungi.Mycol Res, 98:705715. 
Giovannetti M, Mosse B (1980) An evaluation of techniques for measuring vesicular ArbuscularMycorrhizal infection in roots. New Phytol 84:489-500

Harrison RW (1955) A method of isolating vesicular-Arbuscularendophy tes from roots. Nature 175:432159

Johnson, D., Booth, R. E., Whiteley, A. S., Bailey, M. J., Read, D. J., Grime, J. P. And Leake, J. R. (2003). Plant community composition affects the biomass, activity and diversity of microorganisms in limestone grassland soil. Eur. J.Soil Biol, 54: 671-677.

Marschner, H. and Dell, B. (1994). Nutrient uptake in Mycorrhizal symbiosis. Plant soil, 159: 89-102.

Morton JB, Benny GL (2001) Two new families of Glomales, Archaeosporaceae and Paraglomaceae, with two new genera Archaeospora and Paraglomus, based on concordant molecular and morphological characters. Mycologia 93:181-195
Morton, J. B. (2001). Taxonomy of VA Mycorrhizal fungi: Classification, nomenclature, and identification. Mycotaxon, 32: 267-324.

Philips, J. H. and Hayman, D. S. (1970). Improved procedures for clearing roots and staining parasitic and vesicular - ArbuscularMycorrhizal fungi for rapid assessment of infection. Transactions of the British Mycological Society, 55: 158-161.

Scheussler, A., Schwarzott, D. and Walker, C. (2001). A new fungal phylum, the Glomeromycota: phylogeny and evolution. Mycol. Res, 105: 14131421

Smith, G.W and Read, D.J. (1997). Mycorrhizal symbiosis. Academic Press, London, UK. Pp.432.

Srivastava, D., Kapoor, R., Srivastava, S.K. and Mukerji, K.G. (1996). Vesicular ArbuscularMycorrhizal-an overview. In: Mukerji, K.G. (eds.) Concepts in Mycorrhizal Research. Kluwer Academic Publishers, Netherlands, pp: 1-5. 